\title{
The examination of the broadleaf evergreen ornamental shrub species in Keszthely
}

\author{
Maráczi, K. \& Baracsi, É. \\ University of Pannonia - Georgikon Faculty of Agricultural Sciences, Department of Horticulture
}

\begin{abstract}
Summary: The examination of production possibilities of woody ornamental shrubs (originating from warmer regions than our country) commenced with the financial support of the INTERREG IIIA Slovenia - Hungary - Croatia programme at the Department of Horticulture of the University of Pannonia's Georgikon Faculty in spring 2007. Our examinations focused on the appearance of species in our country as well as on their frost resistance abilities. The species participating in the experiment are as follows: Abelia grandiflora, Aucuba japonica 'Rozzanie', Calycanthus floridus, Cotoneaster franchettii, Elaeagnus pungens 'Maculata Aurea', Ilex cornuta, Ligustrum sinense, Ligustrum texanum, Nandina domestica, Osmanthus heterophyllus, Perovskia atriplicifolia, Phyllyrea angustifolia, Photinia fraseri 'Red Robin', Prunus lusitanica, Sarcococca hoockeriana, Spartium junceum, Teucrium fruticans, Viburnum cinnamonifolium, Viburnum tinus.
\end{abstract}

Key words: climate change, heat-loving broadleaf evergreen ornamental shrubs, winter resistance

\section{Introduction}

Nursery gardens, as well as other horticultural branches, have to prepare themselves for climate changes. As opposed to herbaceous ornamental plants, the profile change of nursery gardens with woody ornamental plants need a longer period, as the latter plants need some years to grow up. There are a number of regions on Earth, where the climate and the plants share a lot in common with those expected to appear in Hungary (Schmidt, 2004). According to some experts' the long-term weather forecast, the greenhouse effect will result in a drier and sunnier climate and in the case of the possible appearance of Mediterranean climate our winters are about to become milder.

When defining the risks of climate changes in Hungary, it is important to note that the Carpathian Basin is located on the border of the wet oceanic, dry continental and Mediterranean climatic regions (which latter one is dry in summer and wet in winter). In this zone it is possible that our country might get under the effect of any of the three climates even in the case of a minor shift of zones (Mika, 2002). According to the results of Bartholy et al. (2005), in the range of $0.5-4{ }^{\circ} \mathrm{C}$ global warming a few percents of the annual reduction in cloud cover is likely to happen and the yearly average temperature in Hungary will equal to the global and the hemisphere average. In the case of a $1-1,5^{\circ} \mathrm{C}$ temperature rise, a decrease in rainfall is probable, while in the case of a more intense, larger than $1,5^{\circ} \mathrm{C}$ temperature rise an increase in rainfall is more likely. Winters are expected to become warmer and wetter imposing a higher risk of floods. The calculation concerning the effect of a $3{ }^{\circ} \mathrm{C}$ global warming shows a rather uncertain increase in the rainfall. On the basis of estimates we might conclude that temperature averages of many years are about to change in Hungary. Our climate is expected to heat up and become drier. Szalai (2004) says it is a fact that the chances of drought are getting higher in the Mediterranean regions of Europe and the climate of Hungary resembles the climate of the southern countries in this aspect. In the case of Keszthely, statistics prove that the temperature rise is smaller than the changes registered in other Transdanubian stations, according to which the western part of the Hungary had the estimated temperature trend of $0,72-0,85^{\circ} \mathrm{C}$ per 100 years in the period between 1901 and 2000 (Szalai and Szentimrey, 2001).

Heat-loving ornamental trees and ornamental shrubs in Hungary appeared only in botanic gardens and garden collections for many decades. These collections are characterised by meso- or microclimates which usually ensure the survival of plants in the winter period and even a spontaneous spread is possible (Schmidt, 2001). The examination of frost resistance of certain heat-loving woody species commenced decades ago (Schmidt, 1995). The results of these examinations play an important role today, when there is an increase in import at tree nurseries and as a result of this more and more heat-loving (and frost-sensitive) species are planted in public premises and private gardens alike. Literature usually provides information about the frost resistance of species by listing which winter resistance zones the plants fit into. Winter zones of ornamental trees and shrubs were first defined in the USA at the beginning of the $20^{\text {th }}$ century and they refer to such areas where the given species can be safe and survive the winter season. This kind of classification system only considers the winter minimum temperatures. Local observations are as well necessary as surviving the winter period does not only depend on how cold the winter is, but also on how long the cold period is and 
what the summer and the vegetation period were like before. It is also very important whether the sprouts had enough time to ripe and whether they are strong enough before the winter comes (Schmidt and Tóth 2006). As this fact is unfavourable for plant growers and plant owners alike, the frost resistance examination of the growing number of heat-loving ornamental tree and ornamental shrub species in the country is indispensable before they spread widely.

\section{Materials and methods}

The surroundings of Keszthely are suitable for the outdoor planting of heat-loving plants owing to the proximity of Balaton and the sub-Mediterranean environment. Tradesmen and experts assisted us to select the species that participated in the experiment and we collected data concerning commerce and the Hungarian occurrence of species. Our survey and an electronic list of species helped us to do so.

The mostly 60/80 cm 2-5-year-old Italian import broadleaf evergreen ornamental shrubs were planted in the Szendreytelepi Street 0,175 acre experiment station of the University of Pannonia's Georgikon Faculty. 30 plants of each species and breed were selected and planted into according to their growing abilities $-2,5 \times 1,5 \mathrm{~m} ; 2,5 \times 1,0 \mathrm{~m}$ and $1,0 \times 1,1 \mathrm{~m}$ areas. The frost resistance abilities of species were examined in winter 2007/2008 and 2008/2009. Air temperature data were recorded with the help of the Metos meteorological station during the examinations. The state of the experimental plants was observed numerous times during the winter period and the size of the winter damage was determined at the end of February in both years.

Species examined:

\section{Abelia x grandiflora \\ (Caprifoliaceae)}

2. Aucuba japonica 'Rozzanie' (Cornaceae)

3. Calycanthus floridus (Calycanthaceae)

4. Cotoneaster franchettii (Rosaceae)

5. Elaeagnus pungens 'Maculata Aurea' (Elaeagnaceae)

6. Ilex cornuta (Aquifoliaceae)

7. Ligustrum sinense (Oleaceae)

8. Ligustrum texanum (syn.: Ligustrum japonicum var. texanum) (Oleaceae)

9. Nandina domestica (Berberidaceae)

10. Osmanthus heterophyllus (Oleaceae)

\section{Perovskia atriplicifolia (Lamiaceae) \\ 12. Phillyrea angustifolia (Oleaceae) \\ 13. Photinia x fraseri 'Red Robin' (Rosaceae) \\ 14. Prunus lusitanica (Rosaceae) \\ 15. Sarcococca hoockeriana (Buxaceae) \\ 16. Spartium junceum (Fabaceae) \\ 17. Teucrium fruticans (Lamiaceae) \\ 18. Viburnum cinnamonifolium (Caprifoliaceae) \\ 19. Viburnum tinus (Caprifoliaceae)}

\section{Results and Discussion}

We summarised the results of our survey (conducted on the Hungarian occurrence of species in our collection) in Table 1. There are two real novelties in our collection, the Teucrium fruticans and the Viburnum cinnamonifolium. The following four species and breeds (Aucuba japonica 'Rozzanie', Ilex cornuta, Ligustrum texanum, Photinia fraseri 'Red Robin' and Abelia grandiflora, Cotoneaster franchettii, Elaeagnus pungens 'Maculata Aurea', Sarcococca hoockeriana) appear only in one or two garden collections. At ornamental tree nurseries neither Teucrium fruticans nor Viburnum cinnamonifolium can be found at present, and we can say the same for Ilex cornuta, Ligustrum

Table 1: The occurrence of the examined species at tree nurseries and collections

\begin{tabular}{|c|c|c|}
\hline Name of the Species & At Tree Nurseries $^{1}$ & In Collections $^{1}$ \\
\hline Abelia $x$ grandiflora & $1,2,5,7,11$ & 1,6 \\
\hline Aucuba japonica 'Rozzanie' & 13 & 2 \\
\hline Calycanthus floridus & $2,5,8,10,13$ & $2,3,4,5$ \\
\hline Cotoneaster franchettii & 10,12 & 2,3 \\
\hline Elaeagnus pungens 'Maculata Aurea' & $2,5,6,8,11$ & 1,2 \\
\hline Ilex cornuta & - & 2 \\
\hline Ligustrum sinense & - & $2,3,5$ \\
\hline Ligustrum texanum & $1,5,6,11$ & 1 \\
\hline Nandina domestica & 2,10 & $1,2,3,4,6$ \\
\hline Osmanthus heterophyllus & $5,6,8,10,11$ & $1,2,4$ \\
\hline Perovskia atriplicifolia & $1,2,3,5,6,7,10,11,12,13$ & $1,2,4$ \\
\hline Phillyrea angustifolia & - & $2,3,4,6$ \\
\hline Photinia x fraseri 'Red Robin' & $1,2,5,6,7,10,11$ & 1 \\
\hline Prunus lusitanica & - & $1,2,3$ \\
\hline Sarcococca hoockeriana & 8,10 & 1,2 \\
\hline Spartium junceum & 1,8 & $1,2,3,4,5$ \\
\hline Teucrium fruticans & - & - \\
\hline Viburnum cinnamonifolium & - & - \\
\hline Viburnum tinus & $2,5,10,11$ & $1,2,3,4,6$ \\
\hline
\end{tabular}

1 Tree Nurseries: 1 . Tree Nursery - Alsótekeres, 2. Dula Nursery, 3. Gergely Ornamental Tree Nursery, 4. Gurisatti Tree Nursery, 5. Hentz-Kéreg Ornamental Tree Nursery, 6. Horváth Nursery, 7. Mapol Tree Nursery, 8. Prenor Ltd, 9. Silvanus Ornamental Tree Nursery, 10. Simon Nursery, 11. Szalay Ornamental Tree Nursery, 12. Tahi Tree Nursery, 13. Váradi Ornamental Tree Nursery.

2 Collections: 1. BCE Faculty of Horticulture and Botanical Garden, 2. ELTE Botanical Garden, 3. NYME Botanical Garden, 4. PTE Botanical Garden, 5. Szarvasi Pepi Garden, 6. SZE Botanical Garden. 
Table 2: Visible effects of winter damage on the examined species

\begin{tabular}{|c|c|c|}
\hline \multirow{2}{*}{ Species } & \multicolumn{2}{|l|}{ Damage // Symptom } \\
\hline & On the sprouts & On the leaf \\
\hline 1. Abelia grandiflora & Only the sprouts developed in autumn were frozen. & Leaves are brown. \\
\hline 2. Aucuba japonica 'Rozzanie' & - & Black dry spots on $50 \%$ of the leaves. \\
\hline 3. Calycanthus floridus & - & - \\
\hline 4. Cotoneaster franchettii & - & The majority of the leaves lost their shine. \\
\hline 5. Elaeagnus pungens 'Maculata Aurea' & $\begin{array}{l}\text { The sprout ends developed in autumn bent like } \\
\text { a shepherd's stick. }\end{array}$ & $\begin{array}{l}\text { Brown spots and white dry spots on } 40 \% \text { of the } \\
\text { leaves. }\end{array}$ \\
\hline 6. Ilex cornuta & - & Leaves on sprout ends are yellow and sometimes dry \\
\hline 7. Ligustrum japonicum & The sprout ends are yellow. & Pale green leaves. \\
\hline 8. Ligustrum sinense & $\begin{array}{l}\text { The sprout ends developed in autumn bent like } \\
\text { a shepherd's stick. }\end{array}$ & $\begin{array}{l}\text { By the end of the winter season, } 50 \% \text { of the foliage, } \\
\text { the sprouts are swollen. }\end{array}$ \\
\hline 9. Nandina domestica & - & There are some yellow parts on young leaves. \\
\hline 10. Osmanthus heterophyllus & - & - \\
\hline 11. Perovskia atriplicifolia & - & Dry leaves. \\
\hline 12. Phoetinia fraseri 'Red Robin' & Some of the side sprouts developed in autumn are brown. & Pale leaves. \\
\hline 13. Phyllirea angustifolia & - & $\begin{array}{l}\text { Leaves are brown on the upper } 50-10 \mathrm{~cm} \text { of the } \\
\text { sprouts. }\end{array}$ \\
\hline 14. Prunus lusitanica & - & Leaves are closed like spoons. \\
\hline 15. Sarcococca hoockeriana & $\begin{array}{l}\text { The sprout ends developed in autumn bent like } \\
\text { a shepherd's stick. }\end{array}$ & Leaves on sprout ends are yellow. \\
\hline 16. Spartium junceum & $\begin{array}{l}\text { In the case of } 20 \% \text { of the examined plants } \\
\text { the upper } 10-30 \mathrm{~cm} \text { of the sticks are frozen. }\end{array}$ & - \\
\hline 17. Teucrium fruticans & $100 \%$ of the sprouts are frozen & White and brown leaves. \\
\hline 18. Viburnum cinnamonifolium & $\begin{array}{l}\text { The sprout ends developed in autumn froze, but those } \\
\text { underdeveloped before winter time are undamaged. }\end{array}$ & $\begin{array}{l}\text { Leaf edges are brown as well as they are } \\
\text { dry and black. }\end{array}$ \\
\hline 19. Viburnum tinus & $95 \%$ of the flower sprouts are frozen. & Brown leaves. \\
\hline
\end{tabular}

sinense, Phillyrea angustifolia and Prunus lusitanica. Five more species only appear in one or two ornamental tree nurseries (Table 1).

In the first phase of the frost resistance examination i.e. between 18 December, 2007 and 26 February, 2008 the daily air temperature of the experimental area showed the following results: average temperature: $-5.3{ }^{\circ} \mathrm{C}$, maximum temperature: $-1.3^{\circ} \mathrm{C}$, minimum temperature: $-11.8^{\circ} \mathrm{C}$. In this phase December was the coldest month. The observations in the winter of 2008/2009 were performed between December 1, 2008 and 28 February, 2009. Daily air temperature in this period was as follows: average temperature: $-2.1^{\circ} \mathrm{C}$, maximum temperature: $13.2^{\circ} \mathrm{C}$, minimum temperature: $-12.8^{\circ} \mathrm{C}$. Having further examined weather patterns of the two periods, we can say that the second winter of our plant examination in Keszthely was much wetter than usual and January was the coldest month. Species and breeds of the examination were differently affected by the winter weather (Table 2). The Calycanthus floridus, the Cotoneaster franchettii, the Ligustrum sinense, the Nandina domestica, the Osmanthus heterophyllus, the Perovskia artiplicifolia, the Photinia fraseri 'Red Robin', and the Prunus lusitanica were seemingly not damaged; neither their branch system nor their foliage showed effects of the cold. The Abelia grandiflora, the Ilex cornuta, the Ligustrum texanum, the Sarcococca hoockeriana, and the Spartium junceum species showed freezing at the end of the immature sprouts. On the leaves of the Aucuba japonica 'Rozzanie', the Elaeagnus pungens 'Maculata Aurea', the Phillyrea angustifolia, and the Viburnum cinnamonifoliu we found dry spots as a result of freezing. Frost caused more harm to the Teucrium fruticans and the Viburnum tinus, in the case of which species the foliage suffered considerable damage.

Our examinations include the observations of two winter periods. In the case of two species, the Teucrium fruticans and the Viburnum cinnamonifolium we were the first to report on Hungarian experiences gained on frost resistance abilities. We were also the first to perform observations of such a large number of species of Hungarian climate. We are eager to continue our experiments in the following vegetation periods and winters, in order to provide experts (who deal with growing and using new heat-loving broadleaf evergreen woody ornamental shrubs) with more information and thus help them prepare for the climate change.

\section{References}

Bartholy J., Mika J., Pongrácz R. \& Schlanger V. (2005): A globális felmelegedés éghajlati sajátosságai a Kárpát-medencében. (In: TakácsSánta A, eds. Éghajlatváltozás a világban és Magyarországon) 129-131. Mika J. (2002): A globális klímaváltozásról. Fizikai Szemle 9: 258-268. Schmidt G. \& Tóth I. (2006): Kertészeti dendrológia. Mezőgazda Kiadó, Budapest

Schmidt G. (1995): Néhány cserepes dísznövény fagytűrése KÉE Budai Arborétumában. Új Kertgazdaság. 1 (3): 99-100. 
Schmidt G. (2001): Magyar nemesítésű díszfák-díszcserjék és melegigényes exóták a Kertészeti és Szent István Egyetem Budai Arborétumában. Kertgazdaság. 33. (4): 91-94.

Schmidt G. (2004): Klímaváltozás és a Magyarországi dísznövénytermesztés. „Agro-21” Füzetek, 34: 108-125.
Szalai S., Szentimrey T. (2001): Melegedett-e Magyarország éghajlata a XX. században? (In: Dr. sen. Berényi Dénes születésének centenáris jubileumi tudományos ülése. Szász Gábor eds.) DEMTA-OMSZ, Debrecen: 203-214.

Szalai S. (2004): Igazolják-e a felmelegedést a megfigyelt adatok? Természet Világa. 135. (2): 48-50. 